\title{
Refleksi Demokrasi di Indonesia: Demonstrasi Menolak UU Cipta Kerja dalam Media Berita Online
}

\author{
Rivenskly Fahreza A. ${ }^{1}$, Roziana Febrianita ${ }^{2}$, Maudhy S. P. ${ }^{3}$, Clarissa Desiana F. W. ${ }^{4}$ \\ ${ }^{1234}$ Program Studi Ilmu Komunikasi UPN “Veteran” Jawa Timur \\ Contact: roziana.ilkom@upnjatim.ac.id
}

\begin{abstract}
The Job Creation Act (Omnibus-Law) contains several policies that have led to a protest movement in the form of demonstrations related to this regulation. The demonstration was widely covered by online news media in Indonesia. The research method used is qualitative by using news articles as the unit of analysis using the Entman model framing paradigm to see how online news media construct reality. This study focuses on the news of demonstrations against The Job Creation Act reported by Tirto.id and Liputan6.com for the period of October 2020. The purpose of this research is to reveal how Tirto.id and Liputan6.com portrayed the demonstrations as the reflection of democracy in Indonesia. The results show that Tirto.id and Liputan6 have differentiation in interpreting this phenomenon. Tirto.id prioritizes a critical attitude to issues related to reflection of democracy in Indonesia in that context, that in the democratic process there is still violence from the apparatus, annihilation of workers and riots that cause damage to facilities and infrastructure. Meanwhile Liputan6.com tends to develop a positive perspective regarding the democratic process during and after demonstrations occur. That despite violence against journalists, the authorities are still trying to resolve the case and emphasize the government's positive efforts in improving the country's economy through the Job Creation Law.
\end{abstract}

Keywords: Job Creation Law, Democracy Reflection, Framing Analysis, Online News Media

\begin{abstract}
ABSTRAK
UU Cipta Kerja (Omnibus-Law) memuat beberapa kebijakan yang menyebabkan gerakan penolakan berbentuk demonstrasi terkait peraturan ini. Aksi demonstrasi tersebut banyak diberitakan oleh media berita online di Indonesia. Metode penelitian yang digunakan adalah kualitatif dengan menggunakan artikel berita sebagai unit analisis dengan menggunakan paradigma framing model Entman untuk melihat bagaimana media berita online melakukan konstruksi realitas. Penelitian ini memfokuskan pada berita demonstrasi penolakan UU Cipta Kerja yang diberitakan oleh Tirto.id dan Liputan6.com periode Oktober 2020. Tujuan penelitian ini untuk mengungkap bagaimana Tirto.id dan Liputan6.com menggambarkan demonstrasi sebagai sebuah refleksi demokrasi di Indonesia. Hasil penelitian menunjukkan bahwa Tirto.id dan Liputan6 memiliki diferensiasi dalam memaknai fenomena tersebut. Tirto.id lebih mengedepankan sikap kritis kepada isu terkait refleksi demokrasi di Indonesia dalam konteks tersebut, bahwa dalam proses demokrasi masih terdapat kekerasan dari aparat serta kericuhan yang mengakibatkan kerusakan pada sarana dan prasarana. Sementara Liputan6.com cenderung mengembangkan perpektif positif terkait proses demokrasi selama dan setelah demonstrasi terjadi. Bahwa meski terjadi kekerasan terhadap jurnalis namun aparat masih berinisiasi untuk menyelesaikan kasus tersebut serta menitikberatkan upaya positif pemerintah dalam meningkatkan ekonomi negara melalui UU Cipta Kerja.
\end{abstract}

Kata Kunci : UU Cipta Kerja, Refleksi Demokrasi, Analisa Framing, Media Berita Online

\section{Pendahuluan}

Demonstrasi pada penolakan UU Cipta Kerja Omnibus Law merupakan aksi masyarakat di berbagai daerah yang menolak disahkannya Omnibus Law UU Cipta Kerja (Haryanto, 2020). Aksi demonstrasi bertujuan untuk menekan pemerintah dan DPR untuk membatalkan UU tersebut (Haryanto, 2020). Pada salah satu pemberitaannya, Tirto.id menuliskan bahwa pengesahan UU Cipta Kerja Omnibus Law merugikan buruh dan mengabaikan HAM, sehingga menciptakan banyak protes dikalangan masyarakat (Putsanra, 2020). 
Terdapat beberapa poin yang bermasalah dalam UU Cipta Kerja yang menyebabkan terjadinya penolakan dan aksi demo di beberapa daerah di Indonesia. Sedangkan Liputan6.com mengungkapkan bahwa demo Omnibus Law adalah demonstrasi sebagai bentuk penolakan pengesahan Rancangan Undang-Undang (RUU) Omnibus Law Cipta Kerja (Ciptaker). Liputan6 memberitakan bahwa tidak semua pendemo memiliki tujuan yang sama atau dengan alasan yang sama. Terdapat pendemo yang hanya sekedar ikut-ikutan tanpa memiliki alasan dan tujuan yang jelas (Ady, 2020). Selain itu, Liputan6.com juga memberitakan bahwa terdapat beberapa pihak yang menjadi dalang dan menghasut masyarakat untuk melakukan aksi demo (Luqman, 2020).

Kata "Omnibus Law" mulai dibicarakan di Indonesia sejak Jokowi menyatakan gagasannya mengenai Omnibus Law pada 20 Oktober 2019 usai pelantikannya sebagai Presiden Indonesia ke-8. Jokowi mengungkapkan gagasannya tentang Omnibus Law yang akan mengatasi kendala akibat regulasi di Indonesia yang panjang dan tumpeng tindih. Rencana mengenai UU Cipta Lapangan Kerja dan UU Pemberdayaan UMKM diutarakan Jokowi pada kesempatan saat itu. Gagasan tersebut diutarakan akibat banyaknya jumlah produksi regulasi yang ada di Indonesia sesuai pemerintahan yang sedang berlangsung (Indonesia.go.id, 2019). Portal Informasi Indonesia juga menjelaskan mengenai kelebihan dari konsep Omnibus Law dalam menghadapi permasalahan regulasi di Indonesia. Diantaranya yaitu mengatasi konflik peraturan perundang-undangan baik vertical maupun horizontal secara cepat, efektif dan efisien.

Menyeragamkan kebijakan pemerintah baik di tingkat pusat maupun di daerah untuk menunjang iklim investasi; Memangkas pengurusan perizinan lebih terpadu, efisien dan efektif; Mampu memutus rantai birokrasi yang berbelit-belit; Meningkatnya hubungan koordinasi antar instansi terkait karena telah diatur dalam kebijakan omnibus regulation yang terpadu; Adanya jaminan kepastian hukum dan perlindungan hukum bagi para pengambil kebijakan (Indonesia.go.id, 2019)

Rancangan UU Cipta Kerja tersebut dinilai tidak memperhatikan Hak Asasi Manusia (Dipna, 2020). Hal tersebut tentu menimbulkan respon negative dari masyarakat. Aksi demonstrasi dipilih sebagai cara masyrakat untuk menyampaikan pendapatnya. Tidak hanya masyarakat kalangan bawah, atau pekerja kasar saja yang ikut dalam aksi demo, akan tetapi masyarakat kalangan atas bahkan para public figure juga ikut dalam aksi demo yang dilakukan pada akhir bulan Oktober 2020 (Yandri, 2020).

Masyarakat yang berasal dari berbagai macam kalangan sosial juga ikut serta dalam menyuarkan pendapat dan penolakan terhadap RUU tersebut melalui berbagai macam cara dan berbagai macam media. Beberapa fraksi pemerintahan juga mengungkapkan penolakannya, Fraksi PAN dan Fraksi Demokrat mengatakan bahwa RUU Cipta Kerja harus dipertimbangkan kembali (Dipna, 2020). Jika omnibus law yang ditetapkan oleh pemerintah tidak mengindahkan kepentingan rakyat dan justru merugikan rakyat, maka rakyat Indonesia berhak mengemukakan pendapatnya atau memberikan penolakan terhadap ketentuan tersebut.

Media berita online sendiri langsung menaruh posisi sebagai informan terdepan 
mengenai kejadian demonstrasi OL karena kecepatan di media online sendiri cenderung lebih cepat daripada media cetak. Banyak sekali media berita online yang langsung memberitakan kejadian ini secara massif karena pada saat itu juga banyak masyarakat yang ingin tau mengenai aksi demonstrasi ini. Dari adanya pemberitaan ini maka terbentuklah sebuah persepsi antara beberapa elemen masyarakat yang mengikuti pemberitaan ini.

Media online memiliki berbagai macam sudut pandang atau cara yang berbeda dalam menulis berita. Dari beberapa media online yang ada di Indonesia, terdapat dua media yaitu Tirto.id dan Liputan6.com yang dipilih sebagai subjek penelitian yang akan diteliti. Tirto.id dipilih karena Tirto.id merupakan media online yang memilih melaju di jalur jurnalisme presisi atau precision journalism dengan slogan Jernih Mengalir Mencerahkan. Tirto.id meng-klaim bahwa Tirto.id tidak bekerja untuk kepentingan politik manapun dan merupakan media online yang terdiri dari berbagai macam golongan serta non-partisipan (Tirto.id, 2016).

Tirto.id merupakan basis media online yang sudah ada cukup lama di Indonesia dan bisa dikatakan memiliki pengikut atau penikmat yang cukup banyak. Tirto.id juga mengepakkan sayapnya di media sosial seperti facebook, twitter dan Instagram. Karena di media sosial sendiri bisa menarik antusiasme para anak muda dengan sajian yang dikemas bisa diterima oleh semua kalangan dan tirto ini sendiri memiliki ciri khas dalam penyajian bentuk beritanya di media sosial yang selalu menggunakan plesetan ilustrasi yang bisa menjadi clickbait di platform tersebut. (Kompasiana.com, 2019)

Tirto.id adalah media yang menarik untuk diteliti karena tirto.id merupakan salah satu media Indonesia yang pertama kali lolos verifikasi yang diperiksa oleh Jaringan Periksa Fakta Internasional atau biasanya disebut sebagai International Fact-Checking Network (IFCN). Dan IFCN sendiri merupakan sebuah jaringan media internasional yang memiliki tugas untuk meminimalisir berita yang sekiranya merupakan berita palsu dengan cara pemeriksaan fakta serta penjelasan dari pemberitaan tersebut secara rinci dan di ASEAN sendiri baru ada tiga media seperti Rappler dan Vera files yang berasal serta Tirto.id dari Indonesia sendiri yang memiliki verifikasi IFCN (Nila, 2018). Dengan ini Tirto.id menjadi salah satu media independent yang memiliki kredibilitas yang tinggi dalam memuat informasi berita apapun karena sudah memiliki verifikasi tersebut (Nila, 2018). Sehingga dalam penelitian kami mengenai kontruksi berita pada pemberitaan Omnibus Law selama bulan Oktober 2020 memiliki keakuratan data baik dalam bentuk foto, kutipan, rekaman, serta data baik infografis ataupun dalam bentuk video yang diteliti dan dalam penelitian ini.

Berdasarkan penjelasan diatas, maka penelitian ini ingin mengungkap konstruksi Tirto.id dan Liputan6.com selama bulan Oktober 2020 tentang demonstrasi Omnibus Law. Hal tersebut menarik untuk diteliti sebab isu mengenai Omnibus Law merupakan isu yang kontroversial dan menimbulkan banyak reaksi masyarakat. Fokus dari penelitian ini adalah melihat bagaimana konstruksi Tirto.id dan Liputan6.com terkait perilaku polisi ketika demo Omnibus Law, bagaimana sikap birokrat terkait demo Omnibus Law, dan peristiwa pembakaran halte TransJakarta ketika demo Omnibus Law. Penelitian ini bertujuan untuk melihat bagaimana media tersebut meng-konstruksi atau mem-framing pemberitaan terkait demonstrasi Omnibus Law sebagai bagian dari proses demokrasi di Indonesia. 
Demokrasi menurut Miriam Budiarjo adalah kebijakan umum yang ditentukan atas dasar mayoritas oleh wakil yang dipilih oleh rakyat dalam pemilihan. Sementara Huntington menyatakan demokrasi dapat terjadi dengan dilaksanakannya pemilu yang jujur, adil, dilakukan secara berkala, dan pembagian kekuasaan yang harus jelas. Di Indonesia sejak awal merdeka sistem politik yang digunakan kerap berganti, mulai dari parlementer, orde lama orde baru, hingga akhirnya masuk ke penghujung yaitu era reformasi pada tahun 1998 (Budiarjo, Miriam dalam Idil A, 2016)

Omnibus Law menjadi topik yang hangat dibicarakan di Indonesia usai DPR DPD dan perwakilan pemerintahan Joko Widodo menyetujui agar Omnibus Law RUU Cipta Kerja dapat ditetapkan menjadi undang undang pada awal oktober 2020. Omnibus Law sendiri merupakan gagasan dari presiden RI Joko Widodo untuk mengatasi permasalahan rumitnya perizinan serta tumpang tindihnya peraturan yang dapat menghambat investasi. Ada 3 peraturan yang akan dimuat dalam Omnibus Law yaitu RUU cipta lapangan kerja, RUU perpajakan, dan RUU pemberdayaan masyarakat. Dengan demikian UU Omnibus ini akan menggantikan sebagian atau bahkan keseluruhan dari undang-undang yang telah ada dan terkait dengan klaster poin yang ada pada UU Omnibus tersebut (Prabowo A.S, 2020).

\section{Media Berita Online}

Kemunculan konvergensi media lahir sebagai jawaban atas tuntutan di era digital sekarang ini. Konvergensi media memengaruhi proses jurnalistik serta praktik editorial. Mayoritas perusahaan media sekarang ini menciptakan media berita multiplatform dimana didalam praktiknya menerapkan "one newsroom" yaitu model dari semua platform yang dimiliki oleh perusahaan yang sama akan menggabungkan ke kantor pusat. Setelah banyaknya media konvensional yang bertransformasi dalam bentuk media baru, mediamorfosis pun tidak langsung (Alfiah, K., A., 2019).

Fidler (1997) berpendapat bahwa mediamorfosis merupakan metode penyatuan evolusi teknologi di media komunikasi. Fiddler mendefinisikan mediamorfosis sebagai transformasi media komunikasi yang biasanya ditimbulkan akibat hubungan timbal balik yang rumit antara berbagai kebutuhan yang dirasakan, tekanan persaingan dan politik, serta berbagai inovasi sosial dan teknologi (Olusola dkk, 2017; Fidler, 2003:35). Dalam bertransformasi, media konvensional dapat dikatakan bermetamorfosis yaitu ketika sebuah bentuk media yang baru ada, maka media yang sudah lebih dahulu ada akan beradaptasi dan langsung berkembang bukan mati. Maka dari sana lahirlah portal berita online.

Awal lahirnya jurnalisme online di dunia muncul pada tahun 1990-an setelah teknologi internet mulai berkembang. Di indonesia munculnya media online pertama dimulai oleh Tempo dan detik.com pada tahun 1996. Detik.com adalah satu-satunya media online berupa portal berita pertama di Indonesia yang benar-benar menerbitkan serta menjual konten secara real time sedangkan media online lainnya merupakan versi atau bentuk berita dari majalah atau koran masing-masing. Lalu pada tahun 2000-an Hary Tanoe Soedibjo juga mengepakkan sayapnya ke media berita online melalui okezone.com yang berada dibawah PT. Media Nusantara Citra Group (Gladiaventa, 2016). 


\section{Konstruksi Berita dan Teori Framing Entmann}

Dalam melihat realitas dan kaitannya dengan media terdapat dua perspektif yaitu pluralisme dan konstruksionis. Pluralisme menganggap bahwa realitas tidak terbentuk dengan cara ilmiah, namun realitas terbentuk dengan cara direkonstruksikan dimana hal ini berarti realitas memiliki makna ganda / plural. (Firdaus, 2018). Dalam konstruksi sosial realitas tidak hanya ditransformasikan langsung sebagai berita, ada wartawan atau jurnalis yang ambil andil dalam memaknai realitas. Sedangkan pendekatan konstruksionalis memiliki sudut pandang sendiri terhadap media, wartawan serta berita dipandang (2018). Pertama peristiwa merupakan hasil konstruksionis, dan realitas bersifat subjektif disini berarti realitas dapat tercipta melalui konstruksi dan sudut pandang tertentu dari wartawan. Tidak ada realitas yang bersifat objektif karena realitas tercipta melalui konstruksi serta pandangan tertentu (2014). Kedua pada pandangan konstruksionis, media tidak hanya sekadar saluran atau agen yang bebas, namun juga merupakan subjek yang mengkonstruksi realitas, bias, pandangan, serta pemihakannya. Disini, media dianggap sebagai agen konstruksi sosial yang mendefinisikan realitas. Sehingga media tidak hanya menggambarkan realitas, tidak hanya menunjukkan pendapat dari narasumber berita, namun juga merupakan hasil konstruksi dari media itu sendiri (2014).

Menurut Eriyanto (2002:20 dalam Budi, 2014) berita yang dihasilkan selalu melibatkan pandangan, ideologi, serta nilai-nilai dari wartawan atau media. Bagaimanapun hasil realitas tersebut dijadikan berita sangat tergantung pada bagaimana fakta itu dipahami. Proses pemaknaan tentu saja melibatkan nilai-nilai tertentu sehingga ada kemungkinan berita yang dihasilkan bukan merupakan cerminan dari realitas yang ada. Realitas yang sama bisa saja menghasilkan berita yang berbeda karena sudut pandang yang berbeda.

Ketiga, pandangan konstruksionis menganggap bahwa wartawan tidak dapat menyembunyikan keberpihakannya karena wartawan adalah bagian yang intrinsik dalam proses pembentukan berita. Dengan begitu wartawan dipandang sebagai aktor atau agen konstruksi (Budi, 2014). Wartawan tidak hanya melaporkan fakta namun juga ikut andil dalam mendefinisikan peristiwa sehingga terbentuklah suatu pemahaman oleh khalayak.

Entman (1993) mengembangkan pemahaman analisis framing sebagai metode untuk mengidentifikasi sebuah berita sebagai bagian dari masalah yang memiliki penyebab dan latar belakang, dan karenanya, terdapat cara penyelesaian tersendiri terhadap masing-masing berita. Metode framing Entman juga dilandasi pemahaman kepercayaan bahwa bagaimana pembaca dapat mengartikan sebuah berita sangat bergantung pada kondisi psikis dan fisik pembaca. Maka, untuk menciptakan kohesi, koherensi, konjungsi, dan pemahaman yang komprehensif dan setara antara wartawan/media dan publik pembaca, dibutuhkan pemahaman latar belakang dan ideologi yang relatif sama di antara penulis berita dengan pembaca/konsumen berita. Dalam melihat framing Entmann melihat terdapat dua aspek besar yaitu seleksi isu dan penonjolan aspek tertentu. Dalam framing, apa yang dihilangkan/disamarkan memiliki persamaan dengan pentingnya apa yang harus disematkan dari sebuah teks berita.

Menurut Samsudin (2020 secara praktis Entman membawa empat fungsi 
pembingkaian: pertama, Define Problems mendefinisikan masalah-mengenali apa yang dilakukan agen penyebab, apa kerugian mereka dan keuntungan mereka dan biasanya diukur dengan nilai-nilai budaya. Kedua, Diagnose Cause yaitu mendiagnosa penyebab adalah mengidentifikasi penyebab masalah. Ketiga, Make moral judgement membuat penilaian moral yang mengevaluasi agen penyebab dan efeknya. Keempat, Treatment Recommendation, saran perbaikan adalah menyarankan dan membenarkan perawatan untuk masalah dan memprediksi konsekuensi yang mungkin terjadi. Menurut David (2011) setelah peneliti mengidentifikasi resiko dan manfaat dalam artikel berita, peneliti diinstruksikan untuk mengidentifikasi siapa atau apa yang dianggap bertanggung jawab sebagai interpretasi kausal atau atribusi.

\section{Metode}

Pada penelitian ini, pendekatan yang digunakan adalah pendekatan kualitatif. Hendra Alfani (2020) menyebutkan bahwa penelitian kualitatif adalah penelitian yang bermaksud untuk memahami fenomena apa yang dialami oleh penelitian subjek, dengan cara deskripsi di bentuk kata dan bahasa secara khusus konteks alam dan dengan memanfaatkan berbagai metode ilmiah. Metode penelitian yang digunakan adalah analisa framing model Robert $\mathrm{N}$. Entman. Model ini digunakan untuk menyoroti suatu aspek dari realitas isu yang nantinya akan disebarkan kepada audiens (Annas, dkk, 2021: 54). Pendefinisian masalah digunakan sebagai bingkai untuk melihat suatu peristiwa pada pandangan pertama. Kemudian dicari penyebab masalah dengan menentukan apa dan siapa aktor di balik berita tersebut yang disebut Etnman sebagai interpretasi kausal. (David, 2011). Sumber data utama pada studi ini diperoleh melalui artikel pemberitaan Tirto.id dan Liputan6.com yang berkaitan dengan demo Omnibus Law periode Oktober 2020. Data yang digunakan untuk bahan penelitian adalah berita yang berkaitan dengan demonstrasi penolakan terhadap Omnibus Law.

\section{Hasil dan Pembahasan}

Pada penelitian ini akan menggunakan dua portal berita online yaitu Tirto.id dan Liputan6.com mengenai bagaimana perilaku polisi ketika demo Omnibus Law, bagaimana sikap birokrat terkait demo Omnibus Law, dan peristiwa pembakaran halte TransJakarta ketika demo Omnibus Law. Berita yang digunakan pada penelitian ini dipilih berdasarkan ada atau tidakmya pembahasan mengenai. Penelitian dilakukan untuk mengetahui apakah ada atau tidak berita yang menggambarkan sikap birokrat dan kepolisian pada saat demo Omnibus Law di kedua portal berita online ini. Dengan adanya berita tersebut, maka digunakan tabel di bawah ini untuk menjelaskan temuan dari hasil dari analisis framing yang sudah diteliti di dua portal berita online. 
Tabel 1. Analisis Framing 1

\begin{tabular}{|l|l|l|}
\hline & $\begin{array}{l}\text { Keganasan Polisi ke Jurnalis: } \\
\text { Intimidasi, Hajar, Tangkap } \\
\text { (Sumber: Tirto.id) }\end{array}$ & $\begin{array}{l}\text { Dewan Pers Kutuk Kekerasan } \\
\text { Jurnalis saat Liput Demo Omnibus } \\
\text { Law } \\
\text { (Sumber : Liputan6.com) }\end{array}$ \\
\hline $\begin{array}{l}\text { Apa yang menjadi } \\
\text { penyebab masalah }\end{array}$ & $\begin{array}{l}\text { Jurnalis diintimidasi dan diberikan } \\
\text { sikap tidak baik oleh beberapa } \\
\text { oknum polisi. }\end{array}$ & $\begin{array}{l}\text { Dewan pers memberikan } \\
\text { pernyataan terkait keprihatinan } \\
\text { mengenai apa yang dilakukan oleh } \\
\text { pihak kepolisian dan apa yang } \\
\text { dialami oleh beberapa jurnalis. }\end{array}$ \\
\hline Apa penyebabnya & $\begin{array}{l}\text { Jurnalis terintimidasi karena } \\
\text { menjalankan peliputan berita } \\
\text { mengenai protes masyarakat } \\
\text { pada pengesahan Undang- } \\
\text { Undang Cipta Kerja. }\end{array}$ & $\begin{array}{l}\text { Aparat melakukan Tindakan } \\
\text { kekerasan, intimidasi secara verbal } \\
\text { dan perusakan alat kerja wartawan } \\
\text { yang sedang melakukan } \\
\text { pekerjaannya melibut aksi } \\
\text { demonstrasi. }\end{array}$ \\
\hline Moral concern & $\begin{array}{l}\text { Tindakan intimidasi yang } \\
\text { dilakukan oleh beberapa aparat } \\
\text { kepolisian sangatlah tidak sesuai } \\
\text { dengan UU Pers. }\end{array}$ & $\begin{array}{l}\text { Jurnalis seharusnya tidak } \\
\text { menerima tindak kekerasan yang } \\
\text { berasal dari aparat kepolisian pada } \\
\text { saat meliput kejadian }\end{array}$ \\
\hline $\begin{array}{l}\text { Pengusutan tuntas kasus } \\
\text { kekerasan terhadap jurnalis yang } \\
\text { telah dilakukan oleh beberapa } \\
\text { oknum aparat kepolisian. }\end{array}$ & $\begin{array}{l}\text { Pihak kepolisian bersikap hati-hati } \\
\text { dan tidak melakukan Tindakan } \\
\text { kekerasan terhadap wartawan } \\
\text { yang menjalankan tugas mereka. }\end{array}$ \\
\hline
\end{tabular}

Tabel 2. Analisis Framing 2

\begin{tabular}{|c|c|c|}
\hline & $\begin{array}{l}\text { Tanggapi Mogok \& Demo Buruh } \\
\text { Tolak RUU Ciptaker, Menaker: } \\
\text { Lupakanlah } \\
\text { (Sumber: Tirto.id) }\end{array}$ & $\begin{array}{l}\text { Tanggapi Omnibus Law, Prabowo: } \\
\text { Pemerintah ingin Atasi Masalah } \\
\text { Ekonomi } \\
\text { (Sumber: Liputan6.com) }\end{array}$ \\
\hline $\begin{array}{l}\text { Apa yang menjadi } \\
\text { penyebab masalah }\end{array}$ & $\begin{array}{l}\text { Rencana mogok kerja dan } \\
\text { demonstrasi yang dijalankan } \\
\text { oleh beberapa elemen buruh }\end{array}$ & $\begin{array}{l}\text { Pemerintah ingin segera } \\
\text { mengatasi demonstrasi ini } \\
\text { sehingga dapat mengurangi } \\
\text { hambatan yang terjadi pada } \\
\text { proses kebangkitan ekonomi } \\
\text { Indonesia. }\end{array}$ \\
\hline Apa penyebabnya & $\begin{array}{l}\text { Ancaman mogok nasional yang } \\
\text { membuat menaker memberikan } \\
\text { surat supaya tidak terjadi mogok } \\
\text { nasional karena pandemic } \\
\text { COVID-19 masih tinggi dan } \\
\text { menurut menaker mogok kerja } \\
\text { juga sudah tidak lagi menjadi } \\
\text { relevan karena sudah ada } \\
\text { beberapa aspirasi dari para } \\
\text { buruh yang sudah di akomodir. }\end{array}$ & $\begin{array}{l}\text { Pandemi COVID-19 yang } \\
\text { menyebabkan banyak karyawan } \\
\text { yang di PHK karena dampak } \\
\text { pandemi ini dan dengan adanya } \\
\text { RUU Ciptaker ini pemerintahan } \\
\text { ingin mengatasi masalah ekonomi } \\
\text { yang terjadi di Indonesia ini }\end{array}$ \\
\hline Moral concern & $\begin{array}{l}\text { Menaker memperhatikan } \\
\text { kondisi para buruh yang hendak } \\
\text { mengadakan mogok nasional }\end{array}$ & $\begin{array}{l}\text { Menurut Menhan Prabowo } \\
\text { Pemerintah sendiri memiliki siasat } \\
\text { dengan adanya RUU ini maka bisa }\end{array}$ \\
\hline
\end{tabular}




\begin{tabular}{|l|l|l|}
\hline & $\begin{array}{l}\text { karena pandemi COVID-19 } \\
\text { Masih sedang berlangsung }\end{array}$ & $\begin{array}{l}\text { mengatasi permasalahan } \\
\text { ekonomi yang ada di negara ini }\end{array}$ \\
\hline Saran/solusi & $\begin{array}{l}\text { Pengakomodiran aspirasi dari } \\
\text { para buruh terkait PKWT, }\end{array}$ & $\begin{array}{l}\text { Pemerintah berusaha } \\
\text { memberikan yang terbaik demi } \\
\end{array}$ \\
$\begin{array}{l}\text { Outsourcing, Syarat PHK serta } \\
\text { soal upah yang masih tetap UMK } \\
\text { menjadi sebuah solusi dari } \\
\text { rencana kegiatan mogok kerja } \\
\text { ini }\end{array}$ & negara dan salah satunya dengan \\
& cara RUU Ciptaker ini. \\
\hline
\end{tabular}

Tabel 3. Analisis Framing 3

\begin{tabular}{|c|c|c|}
\hline & $\begin{array}{l}18 \text { Halte Transjakarta Rusak usai } \\
\text { Demo, Kerugian Capai Rp45 } \\
\text { Miliar } \\
\text { (Sumber: Tirto.id) }\end{array}$ & $\begin{array}{l}\text { Mengungkap Misteri Gerombolan } \\
\text { Baju Hitam saat Pembakaran } \\
\text { Halte Sarinah } \\
\text { (Sumber: Liputan6.com) }\end{array}$ \\
\hline $\begin{array}{l}\text { Apa yang menjadi } \\
\text { penyebab masalah }\end{array}$ & 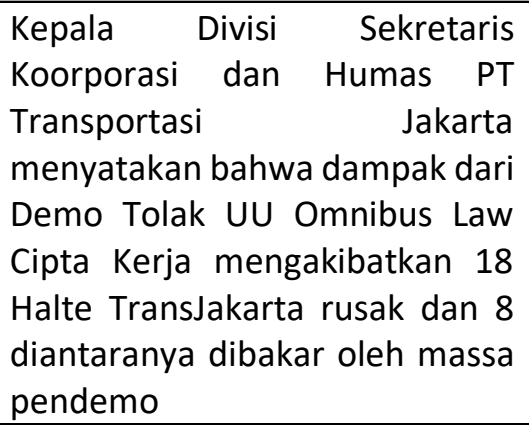 & $\begin{array}{l}\text { Aksi unjuk rasa tolak UU Omnibus } \\
\text { Law Cipta kerja yang berakhir } \\
\text { ricuh mengakibatkan sejumlah } \\
\text { fasilitas publik dirusak salah } \\
\text { satunya halte bus TransJakarta. }\end{array}$ \\
\hline Apa penyebabnya & $\begin{array}{l}\text { Pendemo yang bertindak ricuh } \\
\text { dan akhirnya merusak fasilitas } \\
\text { bahkan membakar publik yang } \\
\text { biasa digunakan untuk mobilitas } \\
\text { warga DKI Jakarta dalam } \\
\text { kesehariannya }\end{array}$ & $\begin{array}{l}\text { Beberapa segerombolan massa } \\
\text { yang misterius yang terekam } \\
\text { CCTV secara terstruktur } \\
\text { melancarkan kegiatan mereka } \\
\text { dalam merusak fasilitas halte } \\
\text { TransJakarta }\end{array}$ \\
\hline Moral concern & $\begin{array}{l}\text { Dampak dari aksi Demo yang } \\
\text { rusuh mengakibatkan kerusakan } \\
\text { terhadap fasilitas publik yang } \\
\text { ada. }\end{array}$ & $\begin{array}{l}\text { Kerusuhan yang terjadi karena } \\
\text { beberapa oknum mengakibatkan } \\
\text { kerugian yang besar. }\end{array}$ \\
\hline Saran/solusi & $\begin{array}{l}\text { Pemerintah memberikan } \\
\text { himbauan kepada warga bahwa } \\
\text { kegiatan aksi demonstrasi tidak } \\
\text { perlu berbuat ricuh hingga } \\
\text { merusak fasilitas publik. }\end{array}$ & $\begin{array}{l}\text { Polisi mengusut tuntas dan } \\
\text { melakukan investigasi terkait } \\
\text { kasus pembakaran halte ini. }\end{array}$ \\
\hline
\end{tabular}

\section{Hasil Analisis Framing Terhadap Pemberitaan Tirto.Id}

Pada pemberitaan pertama yang dimuat di Tirto.id pada 10 Oktober 2020 yang berjudul “Keganasan Polisi ke Jurnalis: Intimidasi, Hajar, Tangkap" ini diunggal oleh Zakki Amali (2020).(Keganasan Polisi ke Jurnalis : Intimidasi, Hajar, Tangkap) menginformasikan terkait aksi demonstrasi penolakan UU Omnibuslaw Cipta Kerja yang dimana para jurnalis mendapatkan Tindakan tidak manusiawi atau Tindakan represif dari oknum aparat kepolisian yang bertugas mengamankan aksi Demonstrasi Tolak UU Omnibuslaw. 
Terdapat salah satu korban bernama Ponco Sulaksono yang merupakan salah satu jurnalis dari portal berita merpatiputih.com, yang pada saat meliput aksi demonstrasi ini dikabarkan hilang yang ternyata pada hari jum'at dini hari ia diketahui telah ditangkap oleh pihak kepolisian dan dengan bukti foto mata lebam dan terdapat darah pada bagian hidung namun belum jelas bagaimana ia mendapatkan luka yang dialaminya, setelah itu dalam pemberitaan ini juga memberitakan bahwa terdapat beberapa jurnalis dari beberapa kota yang sama-sama meliput aksi demonstrasi ini juga menerima tindak kekerasan dari beberapa oknum kepolisian yang bertugas.

Pada pemberitaan ini penulis pada berita ini memiliki sudut pandang yang berbeda, yang dimana berita yang ditulis memiliki beberapa pesan emosional yang ingin disampaikan ke pembaca. dalam pemberitaan ini kita diperlihatkan bagaimana Tindakan kepolisian terhadap para wartawan atau jurnalis yang sedang meliput pada saat aksi demonstrasi terjadi sehingga banyak yang mengecam aksi Tindakan represif yang telah diterima oleh para jurnalis yang berada di lapangan.

Berita kedua yang dimuat di portal berita Tirto.id pada 6 Oktober 2020 yang berjudul "Tanggapi Mogok \& Demo Buruh Tolak RUU Ciptaker, Menaker: Lupakanlah" ini diunggah oleh Selfie Miftahul Jannah (2020). (Tanggapi Mogok \& Demo Buruh Tolak RUU Ciptaker, Menaker: Lupakanlah) memuat berita mengenai surat terbuka dari menteri ketenagakerjaan RI, Ida Fauziyah untuk serikat pekerja dan buruh yang ada di Indonesia untuk tidak melaksanakan mogok nasional pada tanggal 6-8 Oktober 2020 lantaran pandemi COVID-19 masih berlangsung.

Pada berita ini dijelaskan bahwa menurut Ida, Omnibuslaw RUU Cipta Kerja sendiri dirancang untuk menyeimbangkan terkait perlindungan kerja serta memberikan kesempatan bagi orang-orang yang belum memiliki pekerjaan, ia sendiri menyatakan bahwa RUU ini sudah menampung aspirasi masyarakat, serta menurut Ida mogok kerja yang direncanakan oleh beberapa kawan buruh tidak relevan lantaran kondisi sekarang yang dimana pandemi COVID19 masih ada.

Dalam pemberitaan ini memuat banyak kutipan langsung dari Menteri ketenagakerjaan itu sendiri yaitu ibu Ida Fauziyah, karena menurut dia aksi yang hendak diselenggarakan oleh buruh dapat memicu kasus COVID-19 lebih banyak sehingga Menaker menghimbau para kawan buruh/pekerja yang hendak mengikuti aksi ini untuk membatalkannya mengingat virus ini masih belum ditemukan vaksinnya. Menteri juga menuliskan "Lupakanlah rencana itu, jangan ambil resiko membahayakan nyawa kalian, istri, suami dan anak-anak di rumah, mereka wajib kita jaga agar tetap sehat".

Berita ketiga yang dimuat portal berita Tirto.id pada 9 Oktober 2020 yang berjudul "18 Halte TransJakarta Rusak usai Demo, Kerugian Capai Rp45 Miliar" ini diunggah oleh Selfie Miftahul Jannah (2020) (18 Halte TransJakarta Rusak usai Demo, Kerugian Capai Rp45 Miliar) memberitakan bahwa terdapat 18 Halte yang rusak usai aksi demonstrasi ini dan 8 diantaranya dibakar oleh massa sehingga estimasi kerugian yang dialami oleh TransJakarta sekitar Rp45 Miliar. 
Pemberitaan ini sendiri memperlihatkan dimana saja titik kerusakan yang terjadi sehingga pembaca tau bahwa dampak kerusakan usai demo terjadi di beberapa titik di DKI Jakarta serta terdapat 8 titik yang dibakar oleh massa. Terdapat kerugian yang dialami oleh TransJakarta yang juga merugikan para masyarakat yang menggunakan fasilitas publik ini dalam berkegiatan sehari-hari dan pihak TransJakarta mengecam keras aksi perusakan halte yang terjadi pada aksi demonstrasi penolakan RUU Omnibuslaw.

\section{Hasil Analisis Framing Terhadap Pemberitaan Liputan6.Com}

Berita pertama yang dimuat di portal berita Liputan6.com pada 11 Oktober 2020 yang berjudul “Dewan Pers Kutuk Kekerasan Jurnalis saat Liput Demo Omnibus Law” yang diunggah oleh Fachrur Rozie (2020). (Dewan Pers Kutuk Kekerasan Jurnalis saat Liput Demo Omnibus Law) memberitakan respon dewan pers Indonesia terkait kekerasan yang diterima oleh pekerja media dari oknum aparat pada saat meliput aksi demonstrasi Omnibus Law.

Dewan Pers memberikan peringatan terhadap aparat kepolisian yang bekerja pada saat aksi demonstrasi Omnibus Law bahwasanya para pekerja media yang sedang bertugas tersebut dilindungi oleh Undang-Undang Pasal 8 UU Pers no. 40 Tahun 1999 yang menyatakan bahwasanya "'Dalam melaksanakan profesinya wartawan mendapat perlindungan hukum", Dewan pers juga menghimbau pihak keluarga wartawan untuk segera melaporkan ke pihak Dewan Pers apabila terdapat salah satu keluarganya yang berprofesi sebagai wartawan masih tidak ditemukan keberadaannya.

Dalam pemberitaan ini pihak kepolisian juga memberikan alasanya terkait tindakan yang dialami oleh para pekerja media pada saat meliput aksi demonstrasi Omnibus Law, alasan mereka sendiri bahwa mereka tidak mengetahui bahwa yang ditangkap oleh pihak aparat kepolisian ternyata seorang wartawan karena pada saat itu pihak kepolisian menangkap para anarki dan ternyata terdapat seorang wartawan yang ikut tertangkap juga.

Berita kedua yang dimuat Liputan6.com pada 12 oktober 2020 yang berjudul "Tanggapi Omnibus Law, Prabowo: Pemerintah ingin atasi masalah ekonomi" yang diunggah oleh Yusron Fahmi (2020). (Tanggapi Omnibus Law, Prabowo: Pemerintah ingin atasi masalah ekonomi) memberitakan mengenai tanggapan dari Menteri pertahanan Prabowo Subianto terkait RUU Omnibus Law Cipta Kerja yang sudah disahkan oleh DPR serta menanggapi aksi demonstrasi tolak RUU Omnibus Law ini oleh para buruh.

Menteri pertahanan, Prabowo Subianto mengerti bahwa para pemimpin serikat buruh akan membela sesama buruh, namun kita perlu tahu bahwa kondisi negara pada saat ini sedang susah karena pandemi dan ini juga bisa membahayakan ekonomi negara karena akan banyak terjadi PHK dimana-mana, Prabowo mengakui bahwa yang menjadi korbannya adalah kaum buruh, tetapi banyak juga yang menjadi korban di sulitnya masa pandemi ini.

Dalam pemberitaan ini sendiri menunjukan bahwasanya RUU Omnibus Law Cipta Kerja ini menurut Menteri Pertahanan Prabowo Subianto untuk membantu ekonomi negara serta menyayangkan banyaknya pendemo yang belum membaca RUU serta banyaknya hoaks yang bertebaran. 
Berita ketiga yang dimuat portal berita Liputan6.com pada 29 oktober 2020 yang berjudul "Mengungkap Misteri Gerombolan Baju Hitam saat Pembakaran Halte Sarinah" yang diunggah oleh Nanda Perdana Putra (2020). (Mengungkap Misteri Gerombolan Baju Hitam saat Pembakaran Halte Sarinah) yang memberitakan tentang rusaknya fasilitas publik yaitu Halte TransJakarta yang dirusak oleh beberapa oknum misterius selama aksi demonstrasi tersebut terjadi.

Pihak kepolisian bergerak cepat mengusut kasus ini dengan menangkap sejumlah orang yang ditetapkan sebagai tersangka perusakan fasilitas publik, namun terdapat sejumlah temuan mengenai siapa sebenarnya sosok yang membakar halte TransJakarta yang muncul di salah satu video NarasiTV, karena pada rekaman CCTV terdapat tujuh orang yang diduga sebagai pelaku pembakaran yang terjadi di Halte TransJakarta Sarinah.

Pada pemberitaan ini polisi berhasil mengungkap empat orang tersangka pembakaran halte TransJakarta di sarinah berkat rekaman CCTV yang ada disekitaran halte tersebut yang dimana dari hasil rekaman CCTV tersebut pihak kepolisian mengerti bagaimana orang-orang ini melancarkan aksinya, pihak kepolisian mengucapkan terima kasih karena dengan adanya rekaman CCTV tersebut mereka bisa mengusut kasus ini.

\section{Perbedaan Framing Tirto.id dan Liputan6.com tentang sikap birokrat dan kepolisian}

Setiap media massa mempunyai ciri khas yang dirancang untuk menjangkau khalayak luas (McQuail, 2011). Tidak heran jika terdapat perbedaan dalam hal penyajian suatu berita yang dilakukan oleh media massa. Terdapat beberapa faktor yang mempengaruhi pemberitaan, diantaranya adalah sudut pandang apa yang digunakan, latar berlakang kepemilikan media, hegemoni kuasa, dan modal pemberitaan tersebut. Sudut pandang apa yang digunakan mempengaruhi fakta apa yang akan digunakan, bagian mana yang nantinya akan ditonjolkan atau bahkan dihilangkan, dan kemana berita tersebut akan diarahkan (Dhenny, 2017). Keberadaan gatekeeper dalam media secara tidak langsung memberikan kesempatan kepada media tersebut untuk mengemas realita apa yang ingin disajikan sesuai sudut pandang yang diinginkan.

Tirto.id dan Liputan6.com merupakan perusahaan media. Perusahaan tentu memiliki regulasi dan standar pemberitaan tersendiri. Maka dari itu pemberitaan yang dilakukan oleh Tirto.id dan Liputan6.com tidak luput dari konstruksi media. Sudut pandang dan kepentingan kedua media yang berbeda menyebabkan perbedaan bagaimana penyajian berita yang dilakukan oleh kedua media tersebut. Suatu peristiwa bisa dikemas dan diberitakan secara berbeda oleh masing-masing media (Dhenny, 2017).

Pada pemberitaan sikap polisi, Tirto dan Liputan6 menggunakan UU Pers sebagai dasar hukum yang terkait dengan peristiwa tersebut. Keduanya pun memberikan fakta bahwa polisi melakukan tindak kekerasan kepada jurnalis. Akan tetapi, perbedaan pemberitaan kedua media tersebut terlihat pada pemilihan narasumber atau data yang digunakan. Tirto menggunakan fakta atau data dari jurnalis yang menjadi korban kekerasan aparat kepolisia pada saat meliput demo Omnibus Law. Sedangkan Liputan6 menggunakan pernyataan Ketua Dewan Pers sebagai sumber beritanya. Jika Tirto mencantumkan dan menghubungkannya 
dengan berita kekerasan yang pernah dialami oleh jurnalis di Indonesia, maka Liputan6 memberikan ruang atau menyajikan pernyataan dari pihak kepolisian. Tirto juga menuliskan bahwa polisi yang melakukan kekerasan terhadap jurnalis perlu diusut dan diproses dengan benar.

Pada pemberitaan terkait sikap birokrat, Tirto dan Liputan6 sama-sama membingkai pemberitaan tersebut dengan framing bahwa para tokoh pemerintahan tidak setuju dengan adanya aksi demo terkait penolakan Omnibus Law dan menunjukkan bahwa demo Omnibus Law bukanlah suatu hal yang patut untuk dilakukan. Perbedaan dalam pemberitaan Tirto dan Liputan 6 terletak pada pemilihan narasumber. Tokoh birokrasi yang digunakan berbeda, akan tetapi framing pemberitaannya cukup sama. Akan tetapi, Tirto hanya menampilkan pendapat dan respon dari Ida Fauziyah selaku Menteri Ketenagakerjaan RI yang menentang demo tersebut berdasarkan opini pribadinya. Sedangkan Liputan6 mencantumkan pendapat dan respon Prabowo selaku Menteri Pertahanan yang menentang demo tersebut, akan tetapi dengan fakta bahwa masih banyaknya pendemo yang belum membaca isi RUU dan banyaknya masyarakat yang percaya dengan hoaks.

Pemberitaan mengenai pembakaran halte, Tirto.id dan Liputan6.com sama-sama memberitakan bahwa pelaku pembakaran halte adalah oknum tidak bertanggung jawab. Akan tetapi, dengan perbedaan waktu unggah dimana berita milik Tirto merupakan berita dari Oktober awal, dan berita milik Liputan6 merupakan berita dari Oktober akhir menyebabkan adanya beberapa perbedaan diantara kedua berita tersebut. Tirto memilih Nadia Diposanjoyo selaku Humas PT Transportasi Jakarta sebagai narasumber dari pemberitaan tersebut. Tirto sendiri lebih memfokuskan pada kerugiaan dan dampak dari pembakaran tersebut. Karena hingga berita tersebut diberitakan, belum ada bukti akurat mengenai pelaku. Sedangkan Liputan6 menggunakan data dari NarasiTV sebagai sumber pemberitaannya. Liputan6 memberitakan bahwa tersangka yang diamankan polisi berbeda dengan hasil temuan NarasiTV. Pemberitaan tersebut mengarahkan pembaca agar berpikir lebih kritis dan mempertanyakan kebenaran tersangka yang diamankan polisi.

\section{Simpulan}

Dari analisis kedua media berita online tersebut, penulis menyimpulkan bahwa berita tentang demonstrasi penolakan UU Cipta Kerja sebagai berikut: (a) Pemberitaan di Tirto.id menekankan pada isu kekerasan pada jurnalis, kerusakan sarana prasarana serta anihilasi pada kaum buruh. Tirto.id memfokuskan pada hal ini karena sejarah Panjang kekerasan terhadap jurnalis menjadi salah satu elemen demokrasi berproses di Indonesia. Sementara itu jurnalis adalah bagian dari media yang merupakan salah satu pilar dari sebuah negara. Tirto.id juga cenderung menunjukkan tidak didukungnya aksi demonstrasi penolakan UU Cipta Kerja tersebut karena grafik pandemi yang masih cukup tinggi di Indonesia. Penekanan lain dari Tirto.id adalah kerusakan sarana prasarana akibat aksi demonstrasi tersebut merupakan potret sebuah demokrasi berproses di negara ini, sedangkan (b) Liputan6.com lebih menitikberatkan bagaimana Dewan Pers memandang kekerasan terhadap jurnalis tidak mungkin terjadi sebab jurnalis mendapat perlindungan akan hak - haknya. Liputan6.com juga menekankan tidak adanya dukungan dari birokrasi terhadap aksi demonstrasi dengan dasar pernyataan yang 
bahwa pelaku demonstrasi belum membaca dengan seksama UU Cipta Kerja tersebut. Isu lain yang dikedepankan oleh Liputan6.com adalah bahwa UU Cipta Kerja merupakan upaya pemerintah dalam memperbaiki perekonomian negara. Kedua media berita online tersebut memiliki ideologi yang berbeda dalam memaknai serta membingkai realitas untuk dikonstruksikan dalam sebuah perspektif berita. Konstruksi isu dan realitas dalam pemberitaan dilakukan agar pembaca memiliki keseragamaan dan kesamaan makna dengan media tersebut. Liputan6.com berusaha mempersuasi pembaca untuk berpandangan positif terhadap apa yang dilakukan aparat dan birokrasi serta mendukung pemerintah. Sedangkan Tirto.id mengarahkan pembacanya untuk bersikap kritis dan skeptis terhadap realitas yang ada dan bahwa bagaimana sebuah demokrasi berproses di sebuah negara harus dikawal dan dicermati sedemikian rupa.

\section{Daftar Pustaka}

Alfiah, K., A. (2019). Konvergensi Media dan Mediamorfosis: Strategi Digitalisasi Majalah Moeslim Choice dalam Proses Transformasi Basis Kerja. Mediator: Jurnal Komunikasi, 13(1). Diakses pada 17 November 2020, dari http://journal.uinjkt.ac.id/index.php/jsj/article/view/13949/pdf

Alfani, H. (2020). Local Newspaper Strategy to Survive in the Digital Era. Mediator: Jurnal Komunikasi, 13(1). Diakses pada 20 Mei 2021, dari https://doi.org/10.29313/mediator.v13i1.5788

Anugrahadi, A. Cerita Mahasiswa Ikut Demo Tolak Omnibus Law Karena Takut Motor Hilang. Diakses pada 16 November 2020, dari https://www.liputan6.com/news/read/4379277/cerita-mahasiswa-ikut-demotolak-omnibus-law-karena-takut-motornya-hilang

Budi, S. (2014). PERAN MEDIA MASSA DALAM MEMPENGARUHI PERSPEKTIF DAN SIKAP MEMILIH PEMILIH PEMULA DALAM PEMILU PRESIDEN DAN WAKIL PRESIDEN 2014 (Studi Kasus Siswa-Siswi Kelas XII SMA $\begin{array}{lllllll}\text { Negeri } & 1 & \text { Salatiga). } & \text { Diakses } & \text { pada } & 28 & \text { Februari }\end{array}$ https://repository.uksw.edu/bitstream/123456789/10089/1/T1 362007070 Judul.pdf

Damaledo, Y., D. (2020). Jefri Nichol dan Deretan Artis yang Pernah Dukung Aksi Demo. Diakses pada 16 November 2020, dari https://tirto.id/jefri-nichol-dan-deretan-artis-yang-pernah-dukung-aksi-demo-f5Mc

David, Clarissa C.; Atun, Jenna Mae; Fille, Erika; Monterola, Christopher (2011). Finding Frames: Comparing Two Methods of Frame Analysis. Communication Methods and Measures, 5(4), 329-351.

Entman, R. M. (1993). Framing: Toward clarification of a fractured paradigm. Journal of Communication; Autumn 1993; 43, 4; p. 51

Faisal. (2017). Konstruksi Berita Aksi 212 (Analisis Framing di TV One Pada Program Breaking News). Diakses pada 10 Februari 2021, dari http://repositori.uin-alauddin.ac.id/12720/1/FAISALKonstruksi\%20Berita\%20Aksi\%20212.pdf

Firdaus, M. \& Pratiwi, A. F. (2018). Komunikasi Politik Pemerintahan Jokowi-Jk Dalam Perspektif Media. Jurnal Dakwah Tabligh, 16(2), 159-169. Diakses pada 18 November 2020, dari https://doi.org/10.24252/jdt.v16i2.6117

Haryanto, A. (2020). Dampak Omnibus Law Disahkan: Situs DPR Diretas dan Demo Mahasiswa. Diakses pada 16 November 2020, dari https://tirto.id/dampak-omnibus-law-disahkan-situs-dpr-diretas-dan-demomahasiswa-f5Ke

Idil, A. (2016). Demokrasi Dan Gerakan Sosial (Bagaimana Gerakan Mahasiswa Terhadap Dinamika Perubahan Sosial). Jurnal Wacana Politik, 1(2). Diakses pada 17 November 2020, dari http://dx.doi.org/10.24198/jwp.v1i2.11052

Indonesia.go.id. (2019). Omnibus Law: Solusi dan Terbosan Hukum. Diakses pada 16 November 2020, dari https://www.indonesia.go.id/narasi/indonesia-dalam-angka/ekonomi/omnibus-law-solusi-danterobosan-hukum

Khoirulla, A., Abiyu, S., Raihan, S., \& Febrianita, R. (2021). Membingkai Risma di Portal Berita Online: Jejak Penanganan Covid-19 di Surabaya. TUTURLOGI: Journal of Southeast Asian Communication, 2(1). Diakses pada 19 Mei 2021, dari http://dx.doi.org/10.21776/ub.tuturlogi.2020.002.01.4 
Kunhastian, D., K. (2017). KONSTRUKSI BERITA DALAM MAJALAH TEMPO (Analisis Framing Pemberitaan Terorisme di Majalah Tempo Edisi Januari-Februari 2016) (Thesis Dissertation). Universitas Muhammadiyah, Surakarta. Diakses pada 28 Februari 2021, dari http://eprints.ums.ac.id/58014/3/final.pdf

McQuail, D. (2011). Teori Komunikasi Massa (6 $6^{\text {th }}$ ed.). Jakarta: Salemba Humanika. Tersedia dari <https://difarepositories.uin-suka.ac.id/122/1/Teori\%20Komunikasi\%20Masa\%20McQuail.pdf >

Nurkinan,Drs.,M.M. (2017). Dampak Media Online Terhadap Perkembangan Media Konvensional. Diakses pada 16 November 2020, dari https://journal.unsika.ac.id/index.php/politikomindonesiana/article/view/962

Prabowo, A. S., Triputra, A. N., Junaidi, Y., \& Purwoleksono, D. E. (2020). Politik Hukum Omnibus Law di Indonesia. Pamator Journal, 13(1), 1-6. Diakses pada 16 November 2020 dari https://www.researchgate.net/publication/342046925 Politik Hukum Omnibus Law di Indonesia

Reza F. (2013). Konstruksi Berita Kekerasan Densus 88 Kepada Terduga Teroris Di Poso (Analisis Framing Pada Harian Republika). Diakses pada $10 \quad 1021$ Februari http://www.repository.uinjkt.ac.id/dspace/bitstream/123456789/43382/1/REZA\%20FADHILLA-FDK.pdf

Ramadhan, K. (2020). Konstruksi Isu Kekerasan Pada Anak Di Media Online (Analisis Framing Berita Kekerasan Pada Anak Di Media Online Tirto.Id) (Thesis Dissertation). Universitas Islam Negeri, Jakarta. Diakses pada 28 Februari 2021, dari http://repository.uinjkt.ac.id/dspace/bitstream/123456789/52202/1/KALINGGA\%20RAMADHANFDK.pdf

Samsudin, D. 2020. Understanding the Models of Framing Analyses Approaches in Media Framing Studies. In Proceedings of the Second International Conference on Social, Economy, Education and Humanity (ICOSEEH 2019) - Sustainable Development in Developing Country for Facing Industrial Revolution 4.0, pages 385-389

Santo, P. (2019). MEMAHAMI GAGASAN OMNIBUS LAW. Diakses pada 16 November 2020, dari https://businesslaw.binus.ac.id/2019/10/03/memahami-gagasan-omnibus-law/

Sofyan, A. (2013). PEMAKNAAN DEMOKRASI DI ERA REFORMASI (Opini Masyarakat Jawa Tengah terhadap Demokrasi Saat Ini). Politika: Jurnal Ilmu Politik, 4(2). Diakses pada 17 November 2020, dari https://doi.org/10.14710/politika.4.2.2013.5-12 